\title{
HOME RANGE OF A GEOFFROY'S MARMOSET GROUP, Callithrix geoffroyi (PRIMATES, CALLITRICHIDAE) IN SOUTH-EASTERN BRAZIL
}

\author{
PASSAMANI, M. ${ }^{1,2}$ and RYLANDS, A. B. ${ }^{1,3}$ \\ ${ }^{1}$ Departamento de Zoologia, Instituto de Ciências Biológicas, Universidade Federal de Minas Gerais, \\ CEP 31270-901, Belo Horizonte, Minas Gerais, Brazil \\ ${ }^{2}$ Museu de Biologia Prof. Mello Leitão, Av. José Ruschi, 4, CEP 29650-000, Santa Teresa, \\ Espírito Santo, Brazil \\ ${ }^{3}$ Conservação Internacional do Brasil, Avenida Antônio Abrahão Caram, 820/302, CEP 31275-000, \\ Belo Horizonte, Minas Gerais, Brazil \\ Correspondence to: Marcelo Passamani, Museu de Biologia Prof. Mello Leitão, Av. José Ruschi, 4 \\ CEP 29650-000, Santa Teresa, Espírito Santo, Brazil, e-mail: pasamani@npd.ufes.br \\ Received January 13, 1999 - Accepted July 27, 1999 - Distributed May 31, 2000
}

(With 2 figures)

\begin{abstract}
The home range of one group of the Geoffroy's marmoset (Callithrix geoffroyi) was studied in a fragment of the Atlantic Forest in south-eastern Brazil, between February 1993 and January 1994. The total home range was 23.3 ha and the area used in the dry season was significantly larger than that of the wet season. The smallest distance travelled by group was $480 \mathrm{~m} /$ day in May and the longest was 1,980 $\mathrm{m} /$ day in March, but with no significant differences between seasons. The total home range used for this species agrees with the ecological grouping of the genus Callithrix proposed by Rylands \& Faria (1993) and may be associated with the habitat structure, the limit of the fragment and the inexistence of neighbouring groups.
\end{abstract}

Key words: primates, home range, Geoffroy's marmoset, Callithrix geoffroyi, Atlantic Forest.

\section{RESUMO}

\section{Área de uso de um grupo de sagüi-da-cara-branca, Callithrix geoffroyi (Primates: Callithrichidae) no Sudeste do Brasil}

A área de uso de um grupo de sagüi-da-cara-branca (Callithrix geoffroyi) foi estudada em um fragmento de Mata Atlântica no sudeste do Brasil, no período de fevereiro de 1993 a janeiro de 1994. A área de uso total usada pelo grupo foi de 23,3 ha, sendo que a área utilizada na estação seca foi significativamente maior que na estação chuvosa. A distância mínima percorrida pelo grupo foi de 480 $\mathrm{m} /$ dia em maio e a máxima de $1.980 \mathrm{~m} /$ dia em março, não apresentando diferença significativa entre as diferentes estações. O tamanho da área de uso dessas espécies se enquadra no grupamento ecológico do gênero Callithrix, proposto por Rylands \& Faria (1993), e parece estar diretamente associado à estrutura do habitat, ao limite do fragmento e à inexistência de contato com grupos vizinhos.

Palavras-chave: primata, área de uso, sagüi-da-cara-branca, Callithrix geoffroyi, Mata Atlântica.

\section{INTRODUCTION}

The localisation of an animal in space is a result of the interactions between the animal itself and the environment in which it is inserted
(Dawson, 1979). Home range is defined as an area used by an individual or group of individuals during their usual search for resources (Burt, 1943; Jewell, 1966; Bergallo, 1990). In some species, the home range size can be influenced by body size, 
metabolic necessities, social structure and population density, and also, by habitat productivity (MacNab, 1963; Dawson, 1979; Harestad \& Bunnell, 1979).

In the genus Callithrix, home range size varies considerably according to the species and the habitat used. The smallest area registered so far, was 0.5 ha in Callithix jacchus' groups in the cerrado (Stevenson \& Rylands, 1988) and the largest was 35 ha or more in C. flaviceps and $C$. aurita groups in the Atlantic forest (Ferrari, 1988; Corrêa, 1995). Some authors have verified that, in this genus, the differences in structure and floristic composition of the habitat, the availability and abundance of invertebrates and gum trees, and the presence of neighbouring groups can directly influence the home range size of a group (Faria, 1984; Rylands, 1986; Ferrari, 1988; Scanlon et al., 1989; Corrêa, 1995).

Geoffroy's marmoset (Callithrix geoffroyi) originally occurred throughout the Brazilian Atlantic Forest from the state Espírito Santo to southern Bahia and adjacent parts of Minas Gerais State (Rylands et al., 1993). However, this ecosystem has been almost entirely devastated. Currently, only 1 to $5 \%$ remains (Mittermeier et al., 1982), and the species is under increasing threat due to widespread habitat destruction as well as capture for the pet trade (Mendes, 1995). It is among the least studied of the marmoset species.

The aim of this study was to determine the annual and seasonal home range, and the daily route used by a Geoffroy's marmoset group in a fragment of Atlantic Forest in south-eastern Brazil.

\section{METHODS}

This study was carried out in an Atlantic Forest patch of approximately 110 ha belonging to Aracruz Celulose S.A. in the state of Espírito Santo, south-eastern Brazil $\left(19^{\circ} 48^{\prime} \mathrm{S}, 40^{\circ} 7^{\prime} \mathrm{W}\right)$. It is isolated by Eucalyptus plantations, and was selectively logged in the past, resulting in the proliferation of lianas and secondary vegetation up to $10 \mathrm{~m}$ of height (Meira-Neto, 1992). The climate of the region is characterised by a dry season, with less than 70 $\mathrm{mm}$ rainfall each month, from July to November, and a wet season from December to June. Average annual rainfall is around $1,050 \mathrm{~mm}$ (unpublished records from February 1993 to January 1994,
Aracruz Celulose S.A.). The average temperature is $23^{\circ} \mathrm{C}$, but it is slightly cooler from May to October (including most of the dry season) with monthly means ranging from $20.9^{\circ} \mathrm{C}$ to $23.8^{\circ} \mathrm{C}$, than from November to April (early to middle wet season), and with monthly mean temperatures ranging from $25.9^{\circ} \mathrm{C}$ to $27.8^{\circ} \mathrm{C}$ (unpublished records from February 1993 to January 1994, Aracruz Celulose S.A.).

The study group (one adult female, two adult males and two juveniles) was observed from February 1993 to January 1994, after two months of habituation. In January 1994, the group was observed during three complete days; four days in October and December 1993, and five days in the remaining months, for a total of 56 complete days and 464.1 hours of direct observation. Binoculars $(8 \times 40)$ were used during all observations.

In the study area a system of trails was cut forming squares of $30 \times 30 \mathrm{~m}$ the home range was determined by counting the number of squares used by the group throughout the study. The sizes of the squares correspondent to the forest edge, which were smaller than the others, were calculated following the relative size of the area, that is, $25 \%, 50 \%$ or $75 \%$ of the area of a total square (see Ferrari, 1988). The squares occupied by the study group were recorded at each scan sampling (Altmann, 1974) in 5 minutes intervals (Passamani, 1998). To analyse the group's total home range, the number of different squares occupied during the study was summed. To quantify the monthly home range only the squares occupied in the respective month were used. Differential use of squares was determined by the sum of the number of records in which the group was observed in each square. The daily route was measured by plotting on a scaled map the routes of the study group, and only routes of complete observation days were used. Differences in hanging between the dry and wet seasons were tested using the Student $t$ test, with $\mathrm{P}<0,05$ (Siegel, 1956).

\section{RESULTS}

The study group used a total of 259 squares during the year, which is equivalent to a home range of $23.3 \mathrm{ha}$, or about $21 \%$ of the fragment's total area (Table 1). The home range size was significantly larger in the dry season (7.2 ha) than in the wet season (4.9 ha) (Table 1). 
TABLE 1

Seasonal variation in monthly home range and day range length of the $C$. geoffroyi study group.

\begin{tabular}{|c|c|c|c|}
\hline Season & Mean monthly home range (ha) & Day-range length (m) & Standard deviation (m) \\
\hline Dry & 7.2 & 982.5 & 226.3 \\
\hline Wet & 4.9 & 1037.5 & 70.7 \\
\hline Annual total & 23.3 & & - \\
\hline $\mathrm{t}$ & 3.00 & 15.00 & - \\
\hline $\mathrm{n}$ & 12 & 56 & - \\
\hline $\mathrm{p}$ & 0.018 & 0.685 & - \\
\hline
\end{tabular}

$\mathrm{t}=\mathrm{t}$ Student test; $\mathrm{n}=$ sample size; $\mathrm{p}=$ probabilities associated with the test.

There was a strong variation in the home range used by the study group and the areas occupied each month were very small when compared to the total area. In August the study group used a larger area (9.5 ha), while in December and January it occupied smaller areas (2.7 ha and 2.3 ha respectively) (Fig. 1). This figure also shows the cumulative use of squares, according to the observation months, where it can be observed that the curve obtained does not present leveling off.

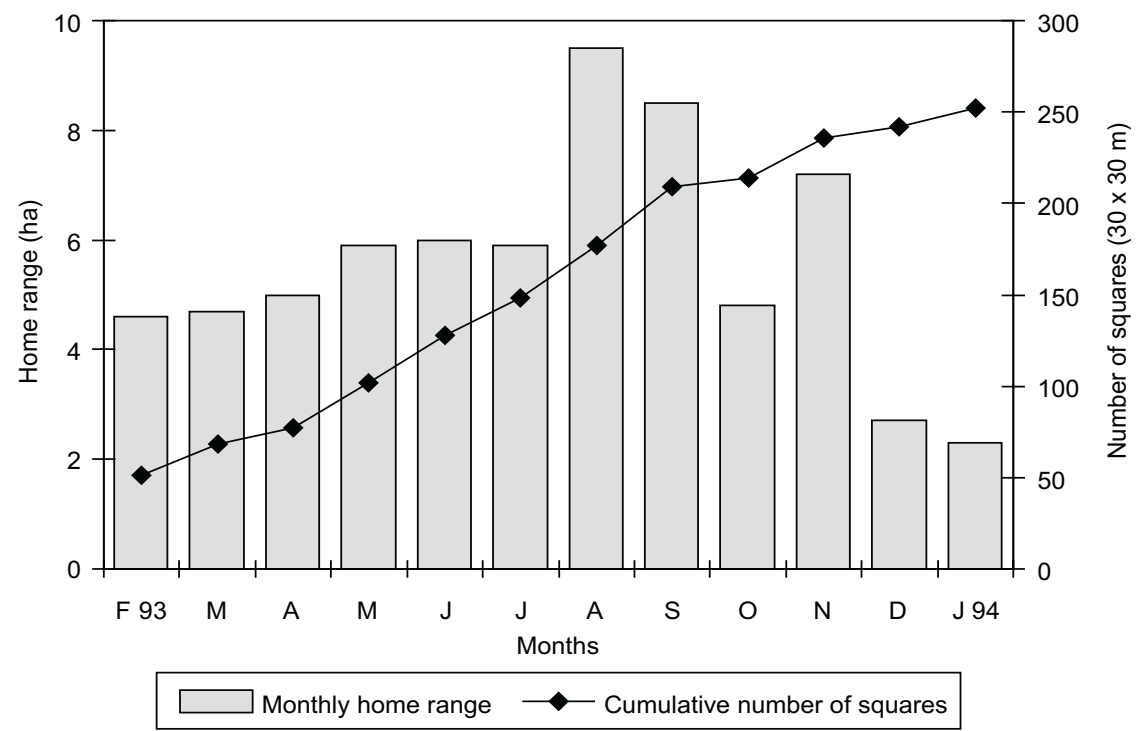

Fig. 1 - Monthly home range and cumulative number of squares used by $C$. geoffroyi study group throughout the year.

The occupied area and its intensity of use demonstrate that the study group used the area in a heterogeneous way, with some squares being more intensively used than others (Fig. 2). In general, the study group concentrated its activities near the fragment's border, where the majority of gum sources were located.
The study group had exclusive use of its home range, since other marmosets groups were absent in the fragment.

During dry season the group travelled an average of $982.5 \mathrm{~m} /$ day and $1037.5 \mathrm{~m} /$ day during the rainy season; these differences were not statistically significant (Table 1). 


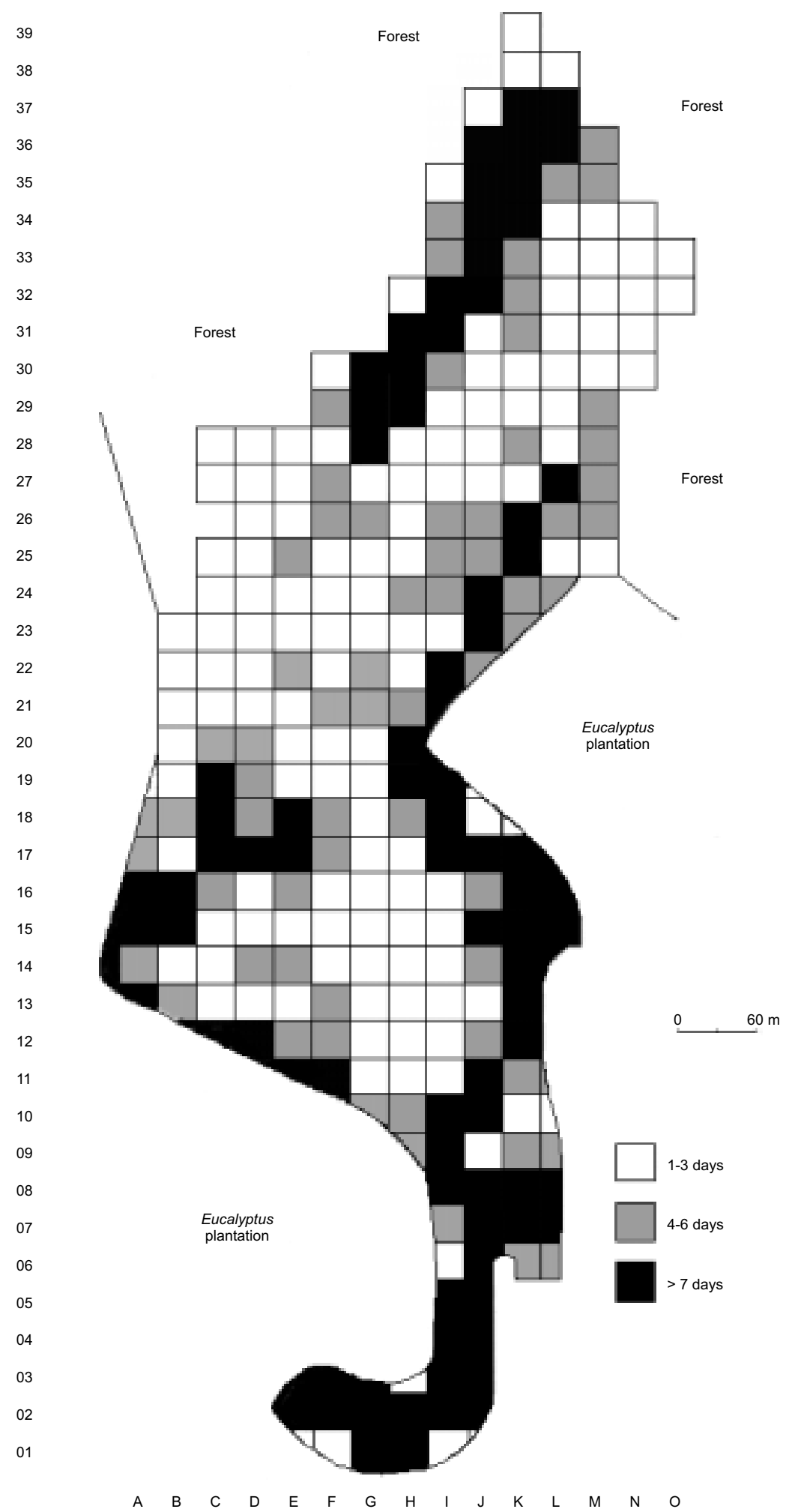

Fig. 2 - Annual home range of the C. geoffroyi study group showing differential use of squares. 
The minimum and maximum distances travelled/day by the study group were $480 \mathrm{~m}$ (May) and $1,980 \mathrm{~m}$ (March), respectively. During movements, the group made use of routes that coincided with the routes used in the previous days.

\section{DISCUSSION}

The only available data about home range used by a group of $C$. geoffroyi were obtained by Rylands \& Costa (1988) at the Peti Station, in Minas Gerais, south-eastern Brazil. These authors estimated the home range size of this species in at 20-30 ha, by dividing the size of station's area by the number of presumed groups present in there. C. geoffroyi's home range size in the present study ( $23.3 \mathrm{ha}$ ) is similar to the one estimated by those authors and is in accordance with the ecological grouping of the genus Callithix, proposed by Rylands \& Faria (1993). According to these authors, due to its ecological characteristics, $C$. geoffroyi should occupy home ranges larger than that of $C$. jacchus and C. penicillata, and smaller than of $C$. aurita and $C$. flaviceps. The home range sizes recorded for species of this genus are variable and obtained in different periods of duration. A C. jacchus group studied during 6 months used an area of 0.5 ha (Stevenson \& Rylands, 1988), while a group of C. flaviceps, studied during 12 months, used an area of 35.5 ha (Ferrari, 1988).

It is known that home range size of an animal is influenced by some factors, such as, body size, metabolic necessities, social structure, population density and habitat productivity (MacNab, 1963; Harestad \& Bunnel, 1979). However, there still is no clarity of the factors that determine the population density of callitrichids species and consequently this home range size. Rylands (1982, 1986) suggested that difference in habitat floristic structure and composition can influence the home range size of Callithrix kuhli and C. intermedia, while Ferrari (1988), studying C. flaviceps and Corrêa (1995), studying C. aurita, argue that these species' home range could be influenced by the availability of invertebrates. These studies demonstrated home range overlap with neighbouring groups, making up more than $50 \%$ of some species areas.
Differently from those species studied, the home range occupied by the study group did not present any overlap with neighbouring groups. In this group, it appears that the home range size is associated with habitat structure, to the fragment's small limit and the lack of contact with neighbouring groups. The predominance of secondary vegetation with an abundance of lianas and gum trees species in the entire fragment (see Meira-Neto, 1992), and the absence of contact with neighbouring groups, may contribute to increase the home range of this group. According to Milton \& May (1976) and Bergallo (1990), the higher the population density of a certain species, the smaller its home range size. In northern of Espírito Santo, population densities estimated for $C$. geoffroyi varied from 0.7 groups/ $\mathrm{km}^{2}$ (Putiri) to 7.5 groups $/ \mathrm{km}^{2}$ (Reserva Florestal da CVRD) and were higher in larger fragments (ca. $20,000 \mathrm{ha}$ ) than in smaller fragments (ca. $200 \mathrm{ha}$ ) (Chiarello, 1997). As in the studied fragment, population density of $C$. geoffroyi is too low (Mendes et al., 1993), the study group may have increased its home range size as a result of reduced or lack of contact with neighbouring groups. Scanlon et al. (1989) verified that the home range size of $C$. jacchus groups can be influenced by the presence of neighbouring groups.

With regard to home range size in each season, the study group used an area significantly larger in the dry than in the wet season. The concentration of the fruit plant species used in December and January, and the small number of gum trees used during this period (Passamani \& Rylands, in press), may have caused the individuals to restrict their home range in that period. On the other hand, during the other months the study group covered a larger area because of the necessity of monitoring a large number of gum sources (Passamani \& Rylands, in press). This corroborates the hypothesis of Faria (1989) which says that the animals use a certain area relates to the number and localisation of gum trees.

The callitrichids' home range pattern can be directly related to the interaction with neighbouring groups and also, to patterns of resources availability (Dawson, 1979; Peres, 1991). Therefore, it is expected that the animals increase their probability of finding resources, and consequently, their home range, if they do not spend time in agonistic intergroup encounters. According to 
Peres (1991), an alternative to minimise the degree of interference with the prediction of resources, is to exclude competitors from the foraging area. This author also verified that Leontopithecus rosalia groups use the squares that are exclusive of themselves much less frequently than the ones where there was overlap with neighbouring groups. Similar results were verified in C. aurita groups (Corrêa, 1995), where the more used regions coincided with overlapping area with neighbouring groups.

In the present study, the lack of overlap with neighbouring groups may have made possible an increase in the home range through a group strategy to invest more time and energy in the search for resources in different areas, instead of increasing the foraging in each area.

The differential utilisation of the group's home range showed a clear tendency of occuping of places where the food resources were more abundant (forest edges). Due to edge effects (e.g. higher exposure to winds, hot air currents and sunlight) the forest edge has higher abundance of sun-loving vegetation, especially vines and lianas (Chiarello, 1997). Thus, the more intense utilisation of squares located near forest borders (areas with altered and denser vegetation), can be related to the supply of gum and insects, as there is evidence that these areas support higher densities of Inga spp. and Bauhinia spp. (Silva, 1993), which are important gum sources for this species (Passamani \& Rylands, in press), and also of arthropods, especially folivorous insects (Janzen, 1973; Cates \& Orians, 1975; Opler, 1978). The more intensively used areas by the study group were directly related to the presence of the main food resources, mainly gum (Passamani \& Rylands, in press). It is ossible that the group movements from area to area to "monitor" gum trees, by doing so also avoid the depletion of food resources.

The routes used by the study group were coincidentally related to the presence of fruit trees and principally, to gum sources (Passamani, 1996). With the exception of the period of higher foraging for insects which occurred between 11:00-14:00 hr (Passamani, 1998), when the study group moved randomly through the area, the movements related to fruit and um use were similar to the ones of the previous days, and the animals looked for routes that appeared to minimise the distance and direction of their food resources. Garber (1989) verified that during foraging for fruits and gum, Saguinus mystax and S. fuscicollis use a oriented movement pattern of the type "straight line", which increases the resources exploration efficiency. Related to the monthly mean distance range of the group, there were no significantly difference between the seasons, similar to the results found for other species of this genus (Rylands, 1982; Stevenson \& Rylands, 1988; Ferrari, 1988; Corrêa, 1995).

Acknowledgments - This field study reported here was kindly financed by Aracruz Celulose S.A. and supported by the Museu de Biologia Prof. Mello Leitão. The research was also supported by a grant from Conselho Nacional de Desenvolvimento Científico e Tecnológico (CNPq), and the United States Fish and Wildlife Service (USFWS) through the Fundação Biodiversitas, Belo Horizonte. I am also grateful to Adriano Chiarello, Marlon Zortéa and Bernardo Brito for their critical comments. Maria Amélia Maciel reviewed the English version of the text.

\section{REFERENCES}

ALTMANN, J., 1974, Observational study of behavior: sampling methods. Behaviour, 49: 227-267.

BERGALLO, H. G., 1990, Fatores determinantes do tamanho da área de vida em mamíferos. Ciência $e$ Cultura, 42: 1067-1072.

BURT, W. H., 1943, Territoriality and home range concepts as applied to mammals. J. Mammal., 24: 346352 .

CATES, R. G. \& ORIANS, G. H., 1975, Successional status and palatability of plants to generalised herbivores. Ecology, 56: 410-418.

CHIARELLO, A. G., 1997, Mammalian community and forest structure of Atlantic forest fragment of southeastern Brazil. Doctoral thesis, University of Cambridge, Cambridge.

CORRÊAA, H. K. M., 1995, Ecologia e Comportamento Alimentar de um Grupo de Sagüis-da-Serra-Escuros (Callithrix aurita E Geoffroy 1812) no Parque Estadual da Serra do Mar, Núcleo Cunha, São Paulo. Master's thesis, Universidade Federal de Minas Gerais, Belo Horizonte.

DAWSON, G. A., 1979, The use of time and space by the Panamanian tamarin, Saguinus oedipus. Folia Primatol., 39: 253-284.

FARIA, D. S., 1984, Aspectos gerais do comportamento de Callithrix jacchus penicillata em mata ciliar de cerrado, pp. 55-66. In: M. T. Mello (ed.), A Primatologia no Brasil. Sociedade Brasileira de Primatologia, Brasília, DF. 
FARIA, D. S., 1989, O estudo de campo com o mico estrela no Planalto Central Brasileiro, pp. 109-121. In: C. Ades (ed.), Etologia de animais e de homens. Edicon/Edusp, São Paulo.

FERRARI, S. F., 1988, The Behaviour and Ecology of the Buffy-Headed Marmoset, Callithrix flaviceps (O. Thomas, 1903). Doctoral thesis, University College London, London.

GARBER, P. A., 1989, Role of spatial memory in primate foraging patterns: Saguinus mystax and Saguinus fuscicollis. Am. J. Primatol., 19: 203-216.

HARESTAD, A. S. \& BUNNELL, F. L., 1979, Home range and body weight - a reevaluation. Ecology, 60: 389-402.

JANZEN, D. H., 1973, Sweep samples of tropical foliage insects: effects of seasons, vegetation types, elevation, times of day and insularity. Ecology, 54: 687708 .

JEWELL, P. A., 1966, The concept of home range in mammals. Symp. Zool. Soc. Lond., 18: 85-109.

MACNAB, B. K., 1963, Bioenergetics and the determination of home range size. Am. Nat., 97: 133-140.

MEIRA-NETO, J. A., 1992, Relatório dos estudos em fragmentos florestais nativos da Aracruz Florestal S.A. Unpublished report, Aracruz Celulose S.A., Espírito Santo.

MENDES, S. L., 1995, Importância dos remanescentes de Mata Atlântica no Estado do Espírito Santo para a conservação de Primatas. Cadernos de Pesquisa da UFES, 4: 1-14.

MENDES, S. L., CHIARELlO, A. G. \& PASSAMANI, M., 1993, Reintrodução do sagüi-da-cara-branca, Callithrix geoffroyi, em seu habitat natural. Unpublished report, Aracruz Celulose S.A./Museu de Biologia Prof. Mello Leitão, Espírito Santo.

MILTON, K. \& MAY, M. L., 1976, Body weight, diet and home range area in primates. Nature, 259: 459462 .

MITTERMEIER, R. A., COIMBRA-FILHO, A. F., CONSTABLE, I. D., RYLANDS, A. B. \& VALLE, C. M. 1982, Conservation of primates in the Atlantic forest region of eastern Brazil. Int. Zoo Yearbook, 22: 2-17.

OPLER, P. A., 1978, Interactions of plant life history components as related to arboreal herbivory, pp. 2331. In: G. G. Montegomery (ed.), The Ecology of Arboreal Folivores. Smithsonian Institution Press, Washington DC, USA.

PASSAMANI, M., 1996, Ecologia e Comportamento de um Grupo de Sagüi-da-Cara-Branca (Callithrix geoffroyi) em um Fragmento de Mata Atlântica no Espírito Santo. Master's thesis, Universidade Federal de Minas Gerais, Belo Horizonte.

PASSAMANI, M., 1998, Activity budget of Geoffroy's marmoset (Callithrix geoffroyi) in an Atlantic Forest in South-eastern Brazil. Am. J. Primat., 46: 333-340.
PASSAMANI, M. \& RYLANDS, A. B., in press, Feeding behavior of Geoffroy's marmoset (Callithrix geoffroyi) in na Atlantic Forest fragment of Southeastern Brazil. Primates.

PERES, C. A., 1991, Intergroup interactions, movements, and use of space in wild golden lion tamarins (Leontopithecus rosalia), pp. 173-190. In: A. B. Rylands \& A. T. Bernardes. A Primatologia no Brasil 3, SBPr/Fundação Biodiversitas, Belo Horizonte.

RYLANDS, A. B., 1982, The Behaviour and Ecology of Three Species of Marmosets and Tamarins (Callitrichidae, Primates) in Brazil. Doctoral thesis, University of Cambridge, London.

RYLANDS, A. B., 1986, Ranging behaviour and habitat preference of a wild marmoset group, Callithrix humeralifer (Callitrichidae-Primates). J. Zool., Lond., 210: $1-26$.

RYLANDS, A. B. \& COSTA, C. M. R., 1988, Observações preliminares sobre as populações de Callithrix geoffroyi (Humboldt, 1912) na Estação de Pesquisa e Desenvolvimento Ambiental de Peti, MG. Unpublished report, Companhia Energética de Minas Gerais, CEMIG, Minas Gerais.

RYLANDS, A. B. \& FARIA, D. S., 1993, Habitats, feeding ecology, and home range size in the genus Callithrix, pp. 262-272. In: A. B. Rylands (ed.), Marmosets and Tamarins. Systematics, Behaviour and Ecology. Oxford University Press, Oxford.

RYLANDS, A. B., COIMBRA-FILHO, A. F. \& MITTERMEIER, R. A., 1993, Systematics, geographic distribution, and some notes on the conservation status of the Callitrichidae, pp. 11-77. In: A. B. Rylands (ed.), Marmosets and Tamarins: Systematics, Behaviour, and Ecology. Oxford University Press, Oxford.

SCANLON, C. E., CHALMERS, N. R. \& MONTEIRO DA CRUZ, M. A. O., 1989, Changes in the size, composition and reproductive condition of wild marmoset groups (Callithrix jacchus jacchus) in northeast Brazil. Primates, 29: 295-305.

SIEGEL, S., 1956, Nonparametric Statistics for the Behavioral Sciences. MacGraw-Hill Press, Tokio, Japan.

SILVA, L. V. C., 1993, Comparação fitossociológica entre duas amostragens numa área de clareira em anos consecutivos, Estação Biológica de Caratinga, MG. Acta Bot. Bras., 7: 119-127.

STEVENSON, M. F. \& RYLANDS, A. B., 1988, The marmosets genus Callithrix, pp. 131-222 In: R. A. Mittermeier, A. B. Rylands, A. F. Coimbra-Filho \& G. A. B. Fonseca (eds.), Ecology and Behavior of Neotropical Primates. vol. 2. World Wildlife Fund, Washington DC. 